\title{
Suppression of Alzheimer's Disease-Related Phenotypes by Expression of Heat Shock Protein 70 in Mice
}

\author{
Tatsuya Hoshino, ${ }^{1}$ Naoya Murao, ${ }^{1}$ Takushi Namba, ${ }^{1}$ Masaya Takehara, ${ }^{1}$ Hiroaki Adachi, ${ }^{2}$ Masahisa Katsuno, ${ }^{2}$ \\ Gen Sobue, ${ }^{2}$ Takahide Matsushima, ${ }^{3}$ Toshiharu Suzuki, ${ }^{3}$ and Tohru Mizushima ${ }^{1}$ \\ ${ }^{1}$ Graduate School of Medical and Pharmaceutical Sciences, Kumamoto University, Kumamoto 862-0973, Japan, ${ }^{2}$ Nagoya University Graduate School of \\ Medicine, Nagoya 466-8550, Japan, and ${ }^{3}$ Graduate School of Pharmaceutical Sciences, Hokkaido University, Sapporo 060-0812, Japan
}

Amyloid- $\beta$ peptide $(\mathrm{A} \beta)$ plays an important role in the pathogenesis of Alzheimer's disease (AD). A $\beta$ is generated by proteolysis of $\beta$-amyloid precursor protein (APP) and is cleared by enzyme-mediated degradation and phagocytosis by microglia and astrocytes. Some cytokines, such as TGF- $\beta 1$, stimulate this phagocytosis. In contrast, cellular upregulation of HSP70 expression provides cytoprotection against $\mathrm{A} \beta$. HSP70 activity in relation to inhibition of $\mathrm{A} \beta$ oligomerization and stimulation of $\mathrm{A} \beta$ phagocytosis has also been reported. Although these in vitro results suggest that stimulating the expression of HSP70 could prove effective in the treatment of AD, there is a lack of in vivo evidence supporting this notion. In this study, we address this issue, using transgenic mice expressing HSP70 and/or a mutant form of APP (APPsw). Transgenic mice expressing APPsw showed less of an apparent cognitive deficit when they were crossed with transgenic mice expressing HSP70. Transgenic mice expressing HSP70 also displayed lower levels of A $\beta$, A $\beta$ plaque deposition, and neuronal and synaptic loss than control mice. Immunoblotting experiments and direct measurement of $\beta$ - and $\gamma$-secretase activity suggested that overexpression of HSP70 does not affect the production A $\beta$. In contrast, HSP70 overexpression did lead to upregulation of the expression of $\mathrm{A} \beta$-degrading enzyme and TGF- $\beta 1$ both in vivo and in vitro. These results suggest that overexpression of HSP70 in mice suppresses not only the pathological but also the functional phenotypes of AD. This study provides the first in vivo evidence confirming the potential therapeutic benefit of HSP70 for the prevention or treatment of AD.

\section{Introduction}

Alzheimer's disease (AD) is characterized pathologically by the accumulation of neurofibrillary tangles and senile plaques, the latter of which are composed of amyloid- $\beta$ peptide $(\mathrm{A} \beta)$, such as $\mathrm{A} \beta 40$ and $\mathrm{A} \beta 42$ (Hardy and Selkoe, 2002; Mattson, 2004). To generate $\mathrm{A} \beta, \beta$-amyloid precursor protein (APP) is first cleaved by $\beta$-secretase and then by $\gamma$-secretase (Hardy and Selkoe, 2002; Mattson, 2004). A $\beta$ can be cleared from the brain via three main pathways: degradation by enzymes, such as neprilysin, insulindegrading enzyme (IDE), and endothelin-converting enzyme 2 (ECE-2), phagocytosis by microglia and astrocytes, and transport into the blood and lymph nodes (Miners et al., 2008; Zlokovic, 2008; Rodríguez et al., 2009). However, monomeric A $\beta$ easily self-assembles to form oligomers, protofibrils, and fibrils, and it is now believed that less aggregated forms of $\mathrm{A} \beta$, such as oligomers and protofibrils, are more important than the highly aggregated forms (Haass and Selkoe, 2007). Therefore, cellular factors

Received Oct. 19, 2010; revised Jan. 11, 2011; accepted Jan. 14, 2011.

This work was supported by Grants-in-Aid for Scientific Research from the Ministry of Health, Labour, and Welfare of Japan, as well as the Japan Science and Technology Agency, Grants-in-Aid for Scientific Research from the Ministry of Education, Culture, Sports, Science and Technology, Japan. We thank Drs. M. Staufenbiel (Novartis Institutes for BioMedical Research, Basel, Switzerland), and C. E. Angelidis and G. N. Pagoulatos (University of Ioannina, loannina, Greece) for providing transgenic mice.

Correspondence should be addressed to Tohru Mizushima, Graduate School of Medical and Pharmaceutical Sciences, Kumamoto University, 5-1 0e-honmachi, Kumamoto 862-0973, Japan. E-mail: mizu@gpo. kumamoto-u.ac.jp.

DOI:10.1523/JNEUROSCI.5478-10.2011

Copyright (C) 2011 the authors $\quad 0270-6474 / 11 / 315225-10 \$ 15.00 / 0$ that affect the production and clearance of $\mathrm{A} \beta$ and/or oligomerization of $A \beta$ may be good targets for the development of drugs to prevent or treat $\mathrm{AD}$.

When cells are exposed to stressors, heat shock proteins (HSPs) are induced, and the cellular upregulation of their expression, especially that of HSP70, provides resistance as the HSPs refold or degrade denatured proteins produced by the stressors (Morimoto and Santoro, 1998; Muchowski and Wacker, 2005). Not only AD but also other neurodegenerative diseases display aggregation of proteins, and overexpression of HSP70 (polyglutamine diseases) or HSP104 (Parkinson's disease) in animal models suppresses the aggregation of each pathogenic protein and ameliorates the corresponding disease symptoms (Adachi et al., 2003; Katsuno et al., 2005; Muchowski and Wacker, 2005; Lo Bianco et al., 2008). An increased level of expression of HSPs, such as small HSPs and HSP70 in the brain of AD patients, has been reported in a number of studies (Perez et al., 1991; Muchowski and Wacker, 2005), with in vitro experiments suggesting that expression of HSPs, in particular HSP70, could suppress the progression of AD (Magrané et al., 2004; Muchowski and Wacker, 2005; Evans et al., 2006; Kumar et al., 2007; Yoshiike et al., 2008). In terms of in vivo studies, the effect of overexpression of HSPs on the pathogenesis of AD has not been examined in vertebrate models. In this study, we investigated the effect of overexpression of HSP70 on AD-related phenotypes, using transgenic mice expressing HSP70 and/or a mutant (Swedish) type of APP (APPsw). Our results demonstrate that overexpression of HSP70 suppresses not only the pathological phenotypes of AD 
but also the resultant cognitive deficits, possibly through its effects on antiaggregation, neuroprotection, and stimulation of $\mathrm{A} \beta$ clearance.

\section{Materials and Methods}

Materials. Eagle's minimal essential medium (EMEM) was obtained from Nissui Pharmaceutical. A fluorescent substrate for $\beta$-secretase $\left[\mathrm{H}_{2} \mathrm{~N}\right.$-ArgGlu-(EDANS)-Glu-Val-Asn-Leu-Asp-Ala-Glu-Phe-Lys-(DABCYL)-Arg-O] was purchased from Calbiochem and that for $\gamma$-secretase [Nma-Gly-GlyVal-Val-Ile-Ala-Thr-Val-Lys(Dnp)-D-Arg-D-Arg-D-Arg- $\left.\mathrm{NH}_{2}\right]$ and synthetic $\mathrm{A} \beta$ were obtained from Peptide Institute. Alexa Fluor 488 goat anti-mouse IgG, Neurobasal medium, B27, and an antibody to $A \beta$ oligomer (A11) were purchased from Invitrogen. Sandwich ELISA (sELISA) kit for A $\beta$ oligomers was obtained from Immunobiological Laboratories. An antibody to actin was obtained from Santa Cruz. Fetal bovine serum (FBS), thioflavin-S, and antibodies to the C-terminal fragment (CTF) of APP and synaptophysin were purchased from Sigma-Aldrich. An antibody to A $\beta$ (6E10) came from Covance Research Products. An antibody to HSP70 was from Assay Designs, and those against neuronal nuclei (NeuN) and presenilin 1 (PS1) were from Millipore Bioscience Research Reagents. The RNeasy kit was obtained from QIAGEN. PrimeScript first-strand cDNA Synthesis kit was from Takara Bio, and iQ SYBR Green Supermix was purchased from Bio-Rad. ELISA kits for tumor necrosis factor- $\alpha$ (TNF- $\alpha$ ), interleukin- $1 \beta$ (IL$1 \beta$ ), and IL- 6 were from Pierce. An ELISA kit for TGF- $\beta 1$ was obtained from R\&D Systems. Sandwich ELISA kits for A $\beta 40$ and $A \beta 42$ and ara-C (cytarabine) were from Wako. Mounting medium for immunohistochemical analysis (VECTASHIELD) was from Vector Laboratories. Mayer's hematoxylin and mounting medium for histological examination (malinol) were purchased from Muto Pure Chemicals. The Envision kit was from Dako.

Animals. Transgenic mice that express APPsw (APP23, C57BL/6) were a gift from Dr. M. Staufenbiel (Novartis Institutes for BioMedical Research, Basel, Switzerland) (Sturchler-Pierrat et al., 1997). Transgenic mice expressing HSP70 were gifts from Drs. C. E. Angelidis and G. N. Pagoulatos (University of Ioannina, Ioannina, Greece) and crossed with C57BL/6 wild-type mice (WT/WT) 10 times to generate WT/HSP70 mice (Tanaka et al., 2007). APP23 male mice were crossed with WT/ HSP70 female mice to generate APPsw/HSP70 mice. Parallel crosses were made between APP23 mice and WT/WT mice to generate APPsw/WT animals. All experiments in this study were done using female mice.

The experiments and procedures described here were performed in accordance with the Guide for the Care and Use of Laboratory Animals as adopted and promulgated by the National Institutes of Health and were approved by the Animal Care Committee of Kumamoto University.

Morris water maze test. The Morris water maze test was conducted in a circular 90-cm-diameter pool filled with water at a temperature of $22.0 \pm$ $1{ }^{\circ} \mathrm{C}$, as described previously (Kobayashi et al., 2000; Huang et al., 2006), with minor modifications. In the hidden platform test, a circular platform $(10 \mathrm{~cm}$ in diameter) was submerged $0.5 \mathrm{~cm}$ below water level. Swimming paths were tracked for $60 \mathrm{~s}$ with a camera and stored in a computer (Video Tracking System CompACT VAS/DV; Muromachi kikai). The mice were given four trials (one block) per day for 7 consecutive days, during which the platform was left in the same position. The time taken to reach the platform (escape latency) was measured, and the average of four trials was determined.

Twenty-four hours after the last trial of the hidden platform test, the mice were subjected to a transfer test in which the platform was removed, and their swimming path was recorded for $60 \mathrm{~s}$. Percentage search time for each quadrant and crossing time in the area where the platform had been located were determined.

sELISA for A $\beta$ or A $\beta$ oligomer and ELISA for cytokines. Cells were cultured for $48 \mathrm{~h}$, and the conditioned medium was subjected to sELISA for $\mathrm{A} \beta$, as described previously (Tomita et al., 1998b; Hoshino et al., 2007a).

$\mathrm{A} \beta 40, \mathrm{~A} \beta 42$, and cytokine levels in the brain were determined as described previously (Iwata et al., 2004). Briefly, the brain hemispheres were homogenized in $50 \mathrm{~mm}$ Tris/HCl buffer, pH 7.6, containing $150 \mathrm{~mm}$ $\mathrm{NaCl}$, and then centrifuged. Guanidine $/ \mathrm{HCl}(0.5 \mathrm{M}$, final concentration) was added to the supernatants (soluble fractions). The precipitates were solubilized by sonication in $6 \mathrm{~m}$ guanidine/ $\mathrm{HCl}$, after which the solubilized pellet was centrifuged and the resulting supernatant diluted (insoluble fractions). The amount of $A \beta 40$ and $A \beta 42$ in each fraction was determined by sELISA. An ELISA assay for $\mathrm{A} \beta$ oligomers or cytokines was performed on the soluble fractions (but without guanidine $/ \mathrm{HCl}$ ), according to the manufacturer's instructions.

Thioflavin-S staining and immunohistochemical analyses. The brain hemispheres were fixed in $4 \%$ buffered paraformaldehyde and embedded in paraffin before being cut into $4-\mu \mathrm{m}$-thick sections, which were then deparaffinized and washed in PBS.

For thioflavin-S staining, sections were stained with $1 \%$ thioflavin-S solution. Samples were mounted with malinol and inspected using a BX51 microscope (Olympus). Fluorescence microscopic images at region $\left(1.0 \mathrm{~mm}^{2}\right)$ in the hippocampus and cerebral cortex were used to calculate the area stained with thioflavin-S using the LuminaVision (Mitani). By determining the threshold optical density, we divided into thioflavin-S-positive and -negative area and the percentage of thioflavin$\mathrm{S}$-positive area to total area was determined. We prepared three sections per mouse and calculated the average of values in three sections.

For immunohistochemical analysis to detect NeuN and HSP70, sections were incubated with $0.3 \%$ hydrogen peroxide in methanol for removal of endogenous peroxidase. They were then blocked with $2.5 \%$ goat serum for $10 \mathrm{~min}$, and incubated for $12 \mathrm{~h}$ with antibody to NeuN (1:1000 dilution) or HSP70 (1:100 dilution) in the presence of $2.5 \%$ bovine serum albumin (BSA), followed by incubation for $1 \mathrm{~h}$ with peroxidaselabeled polymer conjugated to goat anti-mouse (for NeuN) or antirabbit (for HSP70) Ig. 3,3'-Diaminobenzidine was applied to the sections, which were then incubated with Mayer's hematoxylin. Samples were mounted with malinol and inspected using a BX51 microscope. NeuN-positive cells in the pyramidal cell layer of the hippocampal CA3 region (within $500 \mu \mathrm{m}$ from the edge of the dentate gyrus) were counted. We prepared three sections per mouse and calculated the average of values in three sections.

For immunohistochemical analysis to detect synaptophysin, sections were blocked with $2.5 \%$ goat serum (v/v) for 10 min, incubated for $12 \mathrm{~h}$ with antibody to synaptophysin (1:200 dilution) in the presence of $2.5 \%$ BSA, and then incubated with Alexa Fluor 488 goat anti-mouse IgG. Samples were mounted with VECTASHIELD and inspected with the aid of a BX51 fluorescence microscope. Fluorescence intensity in area $(100 \times$ $150 \mu \mathrm{m}$ ) of the hippocampal CA3 region was determined using LuminaVision and shown relative to fluorescence intensity in wild-type mice. We prepared three sections per mouse and calculated the average of values in three sections.

Immunoblotting analysis. Whole-cell extracts were prepared as described previously (Hoshino et al., 2003). The protein concentration of each sample was determined by the Bradford method (Bradford, 1976). Samples were applied to SDS polyacrylamide gels (Tris/tricine gel for detection of $\mathrm{A} \beta, \mathrm{CTF} \alpha$, and CTF $\beta$ or Tris/glycine gel for detection of other proteins) and subjected to electrophoresis, after which proteins were immunoblotted with each antibody.

A dot blotting assay for $\mathrm{A} \beta$ oligomer was performed on the soluble fractions (but without guanidine/ $\mathrm{HCl}$ ), as described previously (Wang et al., 2007). Proteins $(4 \mu \mathrm{g})$ of soluble fractions were applied to nitrocellulose membrane, after which proteins were detected with antibody against $\mathrm{A} \beta$ oligomer (A11).

$\beta$ - and $\gamma$-secretase-mediated peptide cleavage assay. $\beta$ - and $\gamma$-secretase activity was monitored as previously reported (Fukumoto et al., 2002; Farmery et al., 2003). Solubilized membranes were incubated for $1 \mathrm{~h}$ at $37^{\circ} \mathrm{C}$ in $200 \mu \mathrm{l}$ of $50 \mathrm{~mm}$ acetate buffer, $\mathrm{pH} 4.1$, containing $100 \mathrm{~mm}$ sodium chloride, $0.025 \% \mathrm{BSA}$, and $10 \mu \mathrm{M} \beta$-secretase fluorescent substrate or for $4 \mathrm{~h}$ at $37^{\circ} \mathrm{C}$ in $200 \mu \mathrm{l}$ of $50 \mathrm{~mm}$ Tris/HCl buffer, pH 6.8, containing 2 mM EDTA, $0.25 \%$ CHAPSO (3-[(3-cholamidopropyl)dimethylammonio]-2-hydroxy-1propanesulfonate), and $10 \mu \mathrm{M} \gamma$-secretase fluorescent substrate. Fluorescence was measured using a plate reader (Fluostar Galaxy; BMG Labtech) with an excitation wavelength of $355 \mathrm{~nm}$ and an emission wavelength of 510 $\mathrm{nm}$ (for $\beta$-secretase) or $440 \mathrm{~nm}$ (for $\gamma$-secretase).

Real-time reverse transcription-PCR analysis. Real-time reverse transcription (RT)-PCR was performed as previously described (Mima et al., 2005 ) with some modifications. Total RNA was extracted from the brain 

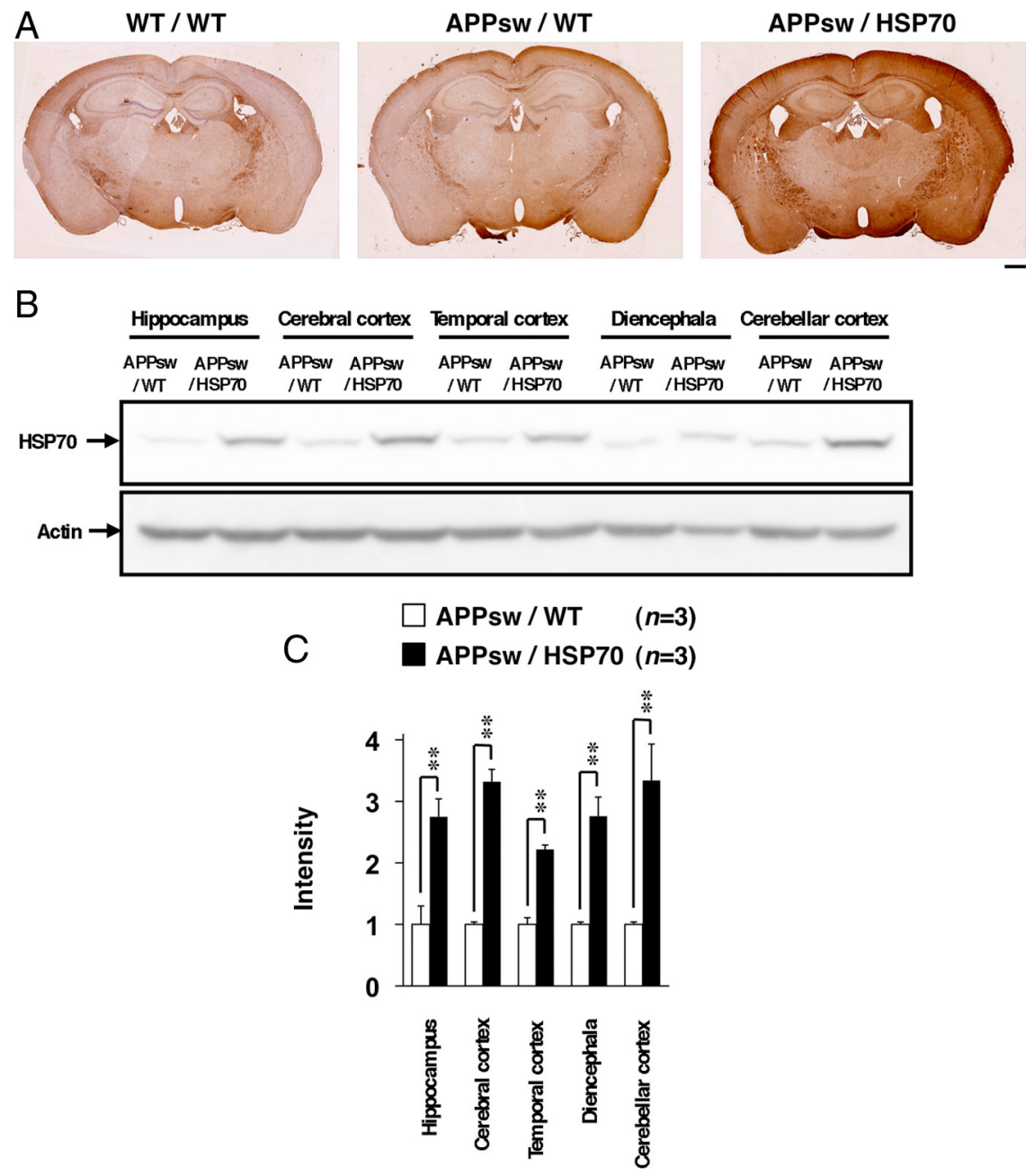

Figure 1. Expression of HSP70 in the brain. $A, B$, Brains were removed from WT/WT, APPsw/WT, and APPsw/HSP70 mice at the age of 18 months. $A$, Sections were prepared and subjected to immunohistochemical analysis with an antibody to HSP70. Scale bar, $500 \mu \mathrm{m} . \boldsymbol{B}$, Brains were divided into fractions containing the hippocampus, cerebral cortex, temporal cortex, diencephala, and cerebellar cortex. Whole-cell extracts were then prepared from each fraction and subjected to immunoblotting with an antibody to HSP70 or actin. C, The band intensity of HSP70 was determined, corrected with that of actin, and expressed relative to the control $(n=3) .{ }^{* *} p<0.01$. Error bars indicate SEM.

or cultured cells using an RNeasy kit according to the manufacturer's protocol. Samples ( $1 \mu \mathrm{g}$ of RNA) were reverse-transcribed using a firststrand cDNA synthesis kit. Synthesized cDNA was used in real-time RT-PCR (Chromo 4 instrument; Bio-Rad) experiments using iQ SYBR GREEN Supermix, and then analyzed with Opticon Monitor Software. Specificity was confirmed by electrophoretic analysis of the reaction products and by inclusion of template- or reverse transcriptase-free controls. To normalize the amount of total RNA present in each reaction, glyceraldehyde-3-phosphate dehydrogenase (GAPDH) cDNA was used as an internal standard.

Primers were designed using the Primer 3 website. The primers used were as follows (name: forward primer, reverse primer): gapdh: $5^{\prime}$-aactttggcattgtggaagg- $3^{\prime}, 5^{\prime}$-acacattgggggtaggaaca-3'; neprilysin: $5^{\prime}$-gcagcctcagccgaaactac-3', 5' -caccgtctccatgttgcagt- $3^{\prime}$; ide: $5^{\prime}$-accaggaaatgttggctgtc- $3^{\prime}, 5^{\prime}$-tctgagaggggaactctcca- $3^{\prime}$; ece-2: $5^{\prime}$-gctatgcccatgtacccagt- $3^{\prime}, 5^{\prime}$-tggcatccagagtacccttc- $3^{\prime}$; il-1 $\beta$ : $5^{\prime}$-gatcccaagcaatacccaaa- $3^{\prime}, 5^{\prime}$-ggggaactctgcagactcaa- $3^{\prime}$; il-6: $5^{\prime}$-ctggagtcacagaaggagtgg- $3^{\prime}, 5^{\prime}$-ggtttgccgagtagatctcaa- $3^{\prime} ;$ tnf- $\alpha$ : $5^{\prime}$-cgtcagccgatttgctatct- $3^{\prime}, 5^{\prime}$-cggactccgcaaagtctaag- $3^{\prime} ;$ tgf- $\beta 1$ : $5^{\prime}$-tgacgtcactggagtacgg$3^{\prime}, 5^{\prime}$-ggttcatgtcatggatggtgc- $3^{\prime}$.

Cell culture. The primary culture of cortical neurons was done as described previously (Saito et al., 2008). The cortex of embryonic day 15.5 mice was dissected. Neurons were spread in a buffer containing papain and cultured at $5 \times 10^{4}$ cells $\mathrm{cm}^{-2}$ in Neurobasal medium containing B27 and antibiotics on poly-D-lysine-coated dishes.
Primary cultures of microglia and astrocytes were prepared as described previously (Kauppinen and Swanson, 2005). The cortex of 1-dold mice was dissected. Cells were spread in a buffer containing papain and DNase and cultured at $1 \times 10^{6}$ cells cm ${ }^{-2}$ in EMEM containing $10 \mathrm{~mm} \mathrm{HEPES} / \mathrm{KOH}$ and $10 \%$ FBS for 2 weeks. Microglial cells were obtained by mildly shaking and collecting the floating cells. For preparation of astrocytes, cells were further incubated in EMEM containing 10 mM HEPES/ $\mathrm{KOH}, 10 \% \mathrm{FBS}$, and $20 \mu \mathrm{M}$ ara-C for $3 \mathrm{~d}$ to induce microglial cell death.

Statistical analysis. All values are expressed as the mean \pm SEM or SD. Two-way ANOVA followed by Tukey's test was used to evaluate differences between more than three groups. Student's $t$ test for unpaired results was used for the evaluation of differences between two groups. Differences were considered to be significant for values of $p<0.05$.

\section{Results \\ Effect of overexpression of HSP70 on cognitive function in transgenic mice expressing APPsw}

To examine the effect of overexpression of HSP70 on the pathogenesis of $\mathrm{AD}$, we used transgenic mice expressing APPsw (APP23, $\mathrm{AD}$ model mice) crossed to transgenic mice that express human HSP70 under the control of the human $\beta$-actin promoter (Plumier et al., 1995). The overexpression of HSP70 in the mice has been demonstrated in various organs, including the brain (Plumier et al., 1997). We first confirmed the expression of HSP70 in the brain by immunohistochemical analysis. As shown in Figure $1 A$, a higher level of HSP70 expression was observed in various brain regions, including the hippocampus and cerebral cortex,intheHSP70transgenicmice(APPsw/ HSP70) at the age of 18 months when compared with the control animals (WT/WT and APPsw/WT). We also compared the level of HSP70 in various parts of the brain by immunoblotting. Higher levels of HSP70 were observed in all regions of the brain tested (hippocampus, cerebral cortex, temporal cortex, diencephala, and cerebellar cortex) in the APPsw/HSP70 mice at the age of 18 months than in the APPsw/WT mice (Fig. $1 B$ ). Similar results were observed APPsw/HSP70 mice at the age of 12 months (supplemental Fig. 1, available at www. jneurosci.org as supplemental material).

We then used a Morris water maze to examine the effect of overexpression of HSP70 on spatial learning and memory. Four strains of mice (WT/WT, WT/HSP70, APPsw/WT, and APPsw/ HSP70) were trained to learn the location of a hidden platform four times per day for $7 \mathrm{~d}$, and the time required to reach the platform (escape latency) was measured. As shown in Figure $2 \mathrm{~A}$, APPsw/WT mice took a significantly longer time than WT/WT mice to reach the platform, a result that is consistent with previous reports (Van Dam et al., 2003) and suggests a deficiency in spatial learning and memory in the former group. This impaired ability of APPsw/WT mice to reach the hidden platform did not reflect reduced swimming ability, as swimming speed and ability to locate a visible platform were indistinguishable between the 

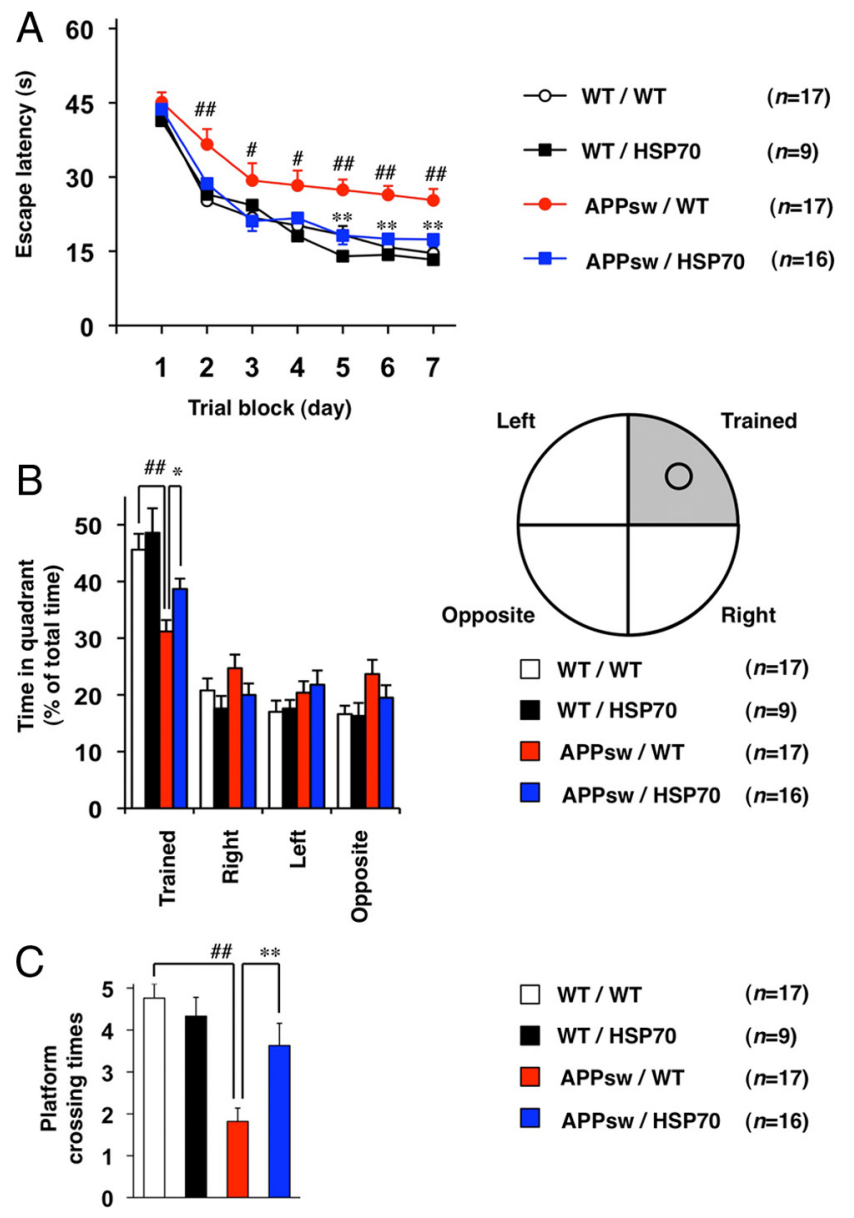

Figure 2. Effects of overexpression of HSP70 on spatial learning and memory in transgenic mice expressing APPsw. Cognitive behavioral tests were performed, using the Morris water maze, on 12-month-old WT/WT ( $n=17)$, WT/HSP70 $(n=9)$, APPsw/WT $(n=17)$, and APPsw/HSP70 mice $(n=16)$ as described in Materials and Methods. The average (4 tests) escape latency in each trial block was measured for $7 \mathrm{~d}(\boldsymbol{A})$, after which the mice were subjected to a transfer test in which the platform was removed. $B$, $C$, The spatial memory for a platform location was estimated by percentage search time for each quadrant (the platform had been located in the "trained" quadrant) $(\boldsymbol{B})$ or platform crossing times $(\boldsymbol{C})$. Values are given as mean \pm SEM. ${ }^{* *} p<0.01,{ }^{*} p<0.05$, versus APPsw/WT mice; ${ }^{\# \#} p<0.01,{ }^{\#} p<0.05$, versus WT/WT mice.

four strains of mice (data not shown). APPsw/HSP70 mice took a significantly shorter time to reach the platform than APPsw/WT mice (Fig. 2A). Furthermore, there was no significant difference in the escape latency between APPsw/HSP70 and WT/WT mice or between WT/HSP70 and WT/WT mice (Fig. 2A). These results suggest that expression of APPsw leads to disturbances in spatial learning and memory, an effect that can be ameliorated by overexpression of HSP70.

We next performed a transfer test to estimate the spatial memory of platform location. After a $7 \mathrm{~d}$ training period (see above), each mouse was subjected to a Morris water maze test in which the platform was removed and the percentage search time for each quadrant was measured. As shown in Figure $2 B$, the ratio of time spent in the trained quadrant was lower for the APPsw/WT group than for either the WT/WT or the APPsw/HSP70 mice. Furthermore, the crossing time of the area where the platform had been located, another indicator of spatial memory, was lower in the APPsw/WT group than in the WT/WT and APPsw/HSP70 cohorts (Fig. 2C). Again, there was no significant difference in these indices between WT/HSP70 and WT/WT mice (Fig. $2 B, C$ ).
These results confirm the notion that overexpression of HSP70 ameliorates the spatial memory deficits of transgenic mice expressing APPsw.

Effect of overexpression of HSP70 on A $\beta$ accumulation and neuronal and synaptic loss in transgenic mice expressing APPsw The amounts of $A \beta 40$ and $A \beta 42$ in soluble and insoluble brain fractions were compared between APPsw/HSP70 and APPsw/WT mice by sELISA. As shown in Figure $3 A$, the levels of $A \beta 40$ and $A \beta 42$ in both brain fractions were lower in the APPsw/HSP70 group than in the APPsw/WT mice.

We then examined the effect of overexpression of HSP70 on plaque deposition and neurotoxicity in APP23 mice. Because plaque deposition and neurotoxicity (neuronal and synaptic loss) were not observed in APP23 mice at the age of 12 months (data not shown), we used mice at the age of 18 months. At first, we compared the level of $\mathrm{A} \beta$ plaque deposition in the brain between APPsw/HSP70 mice and APPsw/WT mice by thioflavin-S staining. As shown in Figure 3, $B$ and $C$, the level of $A \beta$ plaque deposition in both the hippocampus and the cerebral cortex was much lower in the APPsw/HSP70 mice than in the APPsw/WT animals. Very little $\mathrm{A} \beta$ plaque deposition was observed in WT/WT mice (Fig. $3 B, C$ ).

We then compared the number of neurons in the hippocampal CA3 region of APPsw/HSP70 and APPsw/WT mice by NeuN staining. As shown in Figure 3, $D$ and $E$, the number of NeuNpositive cells (neurons) was significantly higher in the WT/WT and APPsw/HSP70 brain sections than in the APPsw/WT tissue, suggesting that $\mathrm{A} \beta$-induced neuronal loss was ameliorated by overexpression of HSP70. We also estimated the number of synapses based on synaptophysin staining. The level of synaptophysin staining was higher in sections from both WT/WT and APPsw/HSP70 mice than from APPsw/WT mice (Fig. $3 F, G)$, indicating that overexpression of HSP70 suppresses $\mathrm{A} \beta$-induced synaptic loss. Together, the results in Figure 3 suggest that overexpression of HSP70 decreases the level of A $\beta$ and $\mathrm{A} \beta$ plaque deposition in the brain and protects it against $\mathrm{A} \beta$-induced neurotoxicity.

\section{Effect of overexpression of HSP70 on the production and oligomerization of $\mathrm{A} \boldsymbol{\beta}$}

To understand the molecular mechanism governing the HSP70mediated decrease in levels of $\mathrm{A} \beta$ and $\mathrm{A} \beta$ plaque deposition, we examined the effect of overexpression of HSP70 on the production of $A \beta$. In general, production of $A \beta$ is regulated by either modification of APP or modulation of secretase activity. We first examined the effect of overexpression of HSP70 on the maturation of APP, an essential step in the production of $\mathrm{A} \beta$. The mature $(N-$ and $O$-glycosylated) and immature ( $N$-glycosylated alone) forms of APP ( $\mathrm{MAPP}$ and imAPP, respectively) can be separated by SDS-PAGE on the basis of molecular weight (Tomita et al., 1998a). As shown in Figure $4 A$, mAPP and imAPP were detected in transgenic mice expressing APPsw, and the total amount of APP and the ratio of $\mathrm{mAPP}$ and imAPP were indistinguishable between APPsw/HSP70 mice and APPsw/WT animals. We also found that overexpression of HSP70 did not affect the level of PS1 (Fig. 4A).

Next, we tested the notion that overexpression of HSP70 affects production of $A \beta$ through modulation of secretase activity by comparing the amount of CTFs, the secreted forms of APP that are generated by $\alpha$ or $\beta$-secretase (CTF $\alpha$ or CTF $\beta$, respectively, known as an indirect index of the secretase activity), between APPsw/HSP70 and APPsw/WT mice. Under our experimental conditions, we could not detect the band of CTF $\gamma$. As shown in Figure $4 B, \mathrm{CTF} \alpha$ and CTF $\beta$ were detected in transgenic mice ex- 
$\square$ APPsw / WT

APPsw / HSP70
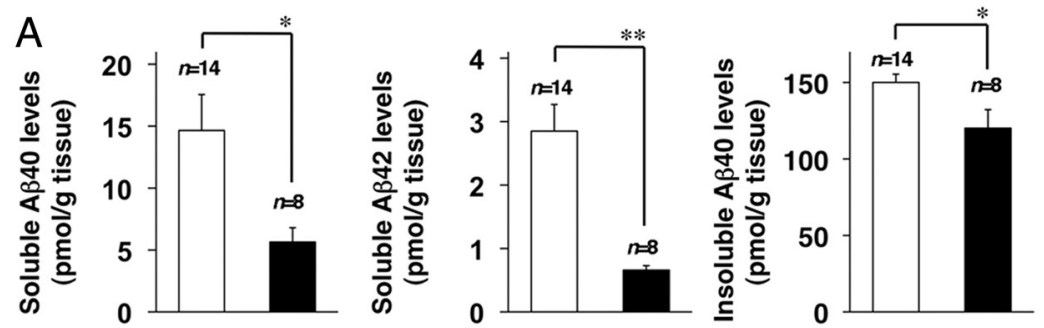

B
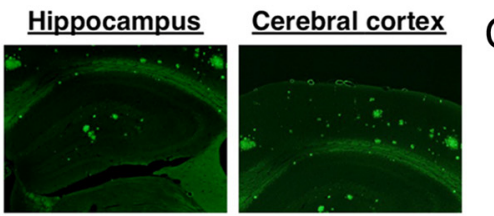

C

Hippocampus

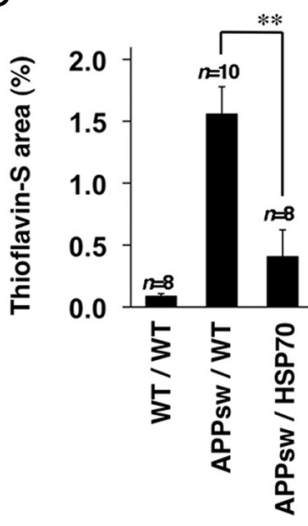

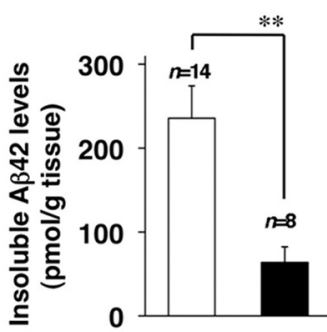

Cerebral cortex

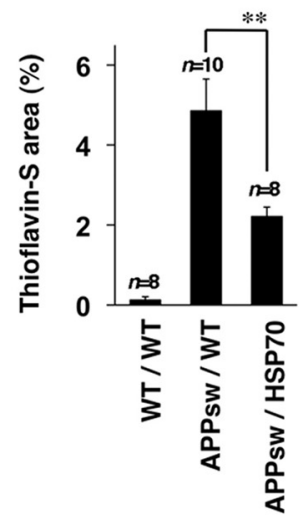

D

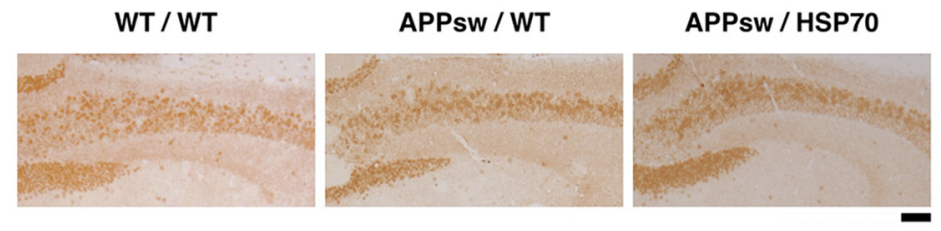

F

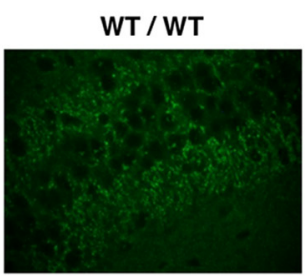

APPsw / WT
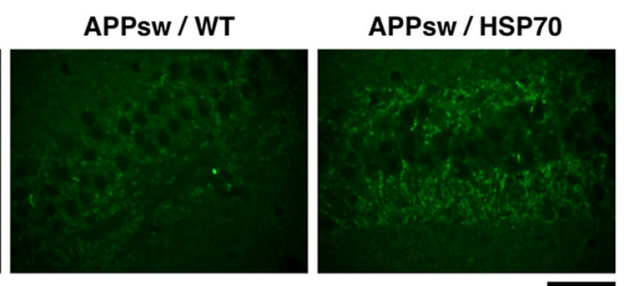

$\mathrm{E}$

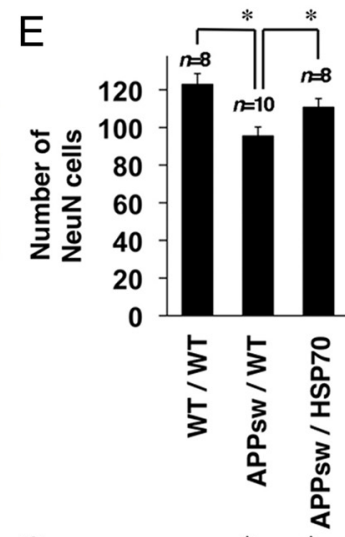

G

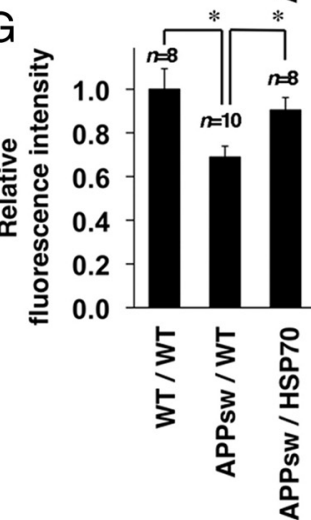

Figure 3. Effects of HSP70 overexpression on A $\beta$ levels, $A \beta$ plaque deposition, and neuronal and synaptic loss in the brain of transgenic mice expressing APPsw. $A$, Soluble and insoluble fractions were prepared from the brains of 12-month-old APPsw/WT $(n=14)$ and APPsw/HSP70 mice $(n=8)$. The amounts of A $\beta 40$ and A $\beta 42$ in each fraction were determined by sELISA as described in Materials and Methods. $\boldsymbol{B}, \boldsymbol{D}, \boldsymbol{F}$, Brain sections were prepared from 18-month-old APPsw/WT $(n=10)$, APPsw/HSP70 $(n=8)$, and WT/WT mice $(n=8)$, and then subjected to thioflavin-S staining $(\boldsymbol{B})$ and immunohistochemical analysis with an antibody to $\mathrm{NeuN}(\boldsymbol{D})$ or synaptophysin $(\boldsymbol{F})$. Scale bars: $\boldsymbol{B}, 200 \mu \mathrm{m} ; \boldsymbol{D}, 100 \mu \mathrm{m} ; \boldsymbol{F}, 50 \mu \mathrm{m}$. $\boldsymbol{C}, \boldsymbol{E}, \boldsymbol{G}$, Relative area stained with thioflavin-S( $\boldsymbol{C}$, number of NeuN-positive cells in hippocampal CA3 region (E), and relative fluorescence intensity (synaptophysin) in hippocampal CA3 region ( $\boldsymbol{G}$ ) (3 sections per brain) were determined. Values are given as mean \pm SEM. ${ }^{* *} p<0.01 ;{ }^{*} p<0.05$. 
pressing APPsw, and the amounts of CTF $\alpha$ and $\mathrm{CTF} \beta$ were indistinguishable between the APPsw/HSP70 and APPsw/WT mice. We then directly measured $\beta$ - and $\gamma$-secretase activity, using the APP-derived fluorescent substrate of each secretase (Hoshino et al., 2009). As shown in Figure $4 C$, the activity was indistinguishable between the APPsw/HSP70 and APPsw/WT groups. These results suggest that overexpression of HSP70 does not affect the production of $A \beta$.

To test this idea in vitro, we prepared primary cultures of neurons from APPsw/ HSP70 and APPsw/WT mice and compared the level and modification of APP in the cells, as well as the level of $A \beta 40$ and $\mathrm{A} \beta 42$ in the culture medium. We also confirmed the overexpression of HSP70 in primary neurons prepared from APPsw/ HSP70 mice (Fig. 4D). As shown in Figure 4, $D$ and $E$, no significant differences were observed in the total amount of APP, the ratio of $\mathrm{mAPP}$ and imAPP, and the levels of $A \beta 40$ and $A \beta 42$ in the primary neuronal cultures between the APPsw/HSP70 and APPsw/WT groups, supporting the idea that overexpression of HSP70 does not affect the production of $A \beta$.

We then compared the level of $A \beta$ oligomer in the brain of APPsw/HSP70 and APPsw/WT mice by immunoblotting analysis. As shown in Figure 5, $A$ and $B$, not only the level of $A \beta$ monomer but also that of $\mathrm{A} \beta$ oligomers (dimer, trimer, and hexamer) was lower in the APPsw/HSP70 animals. The decrease in the level of $\mathrm{A} \beta$ oligomer in the brain of APPsw/HSP70 was confirmed by ELISA assay for $\mathrm{A} \beta$ oligomer (Fig. 5C) and dot-blotting assay with antibody that specifically recognizes oligomer form of $\mathrm{A} \beta$ (A11) (Fig. $5 D, E)$. The specificity of this antibody (A11) to $\mathrm{A} \beta$ oligomer was suggested by the observation that this antibody did not give positive signals against samples from wildtype mice (without expression of APPsw) (supplemental Fig. 2, available at www.jneurosci.org as supplemental material).

We then examined the colocalization of Hsp70 with APP, $\mathrm{A} \beta$, $\mathrm{A} \beta$ oligomer, and $\mathrm{A} \beta$ plaque. Intracellular colocalization of HSP70 with APP and A $\beta$ was observed (supplemental Fig. $3 A, C$, available at www.jneurosci.org as supplemental material). However, extracellular colocalization of HSP70 with A $\beta$ plaque was not observed so clearly (supplemental Fig. $3 B, D$, available at www.jneurosci.org as supplemental material). The intracellular colocalization of HSP70 with A $\beta$ oligomer was also observed in both hippocampus and cerebral cortex (supplemental Fig. 3E, F, available at www.jneurosci.org as supplemental material).

Effect of overexpression of HSP70 on the expression of genes involving $\mathrm{A} \boldsymbol{\beta}$ clearance

As described in Introduction, degradation by enzymes and phagocytosis by microglia and astrocytes are involved in the clearance of
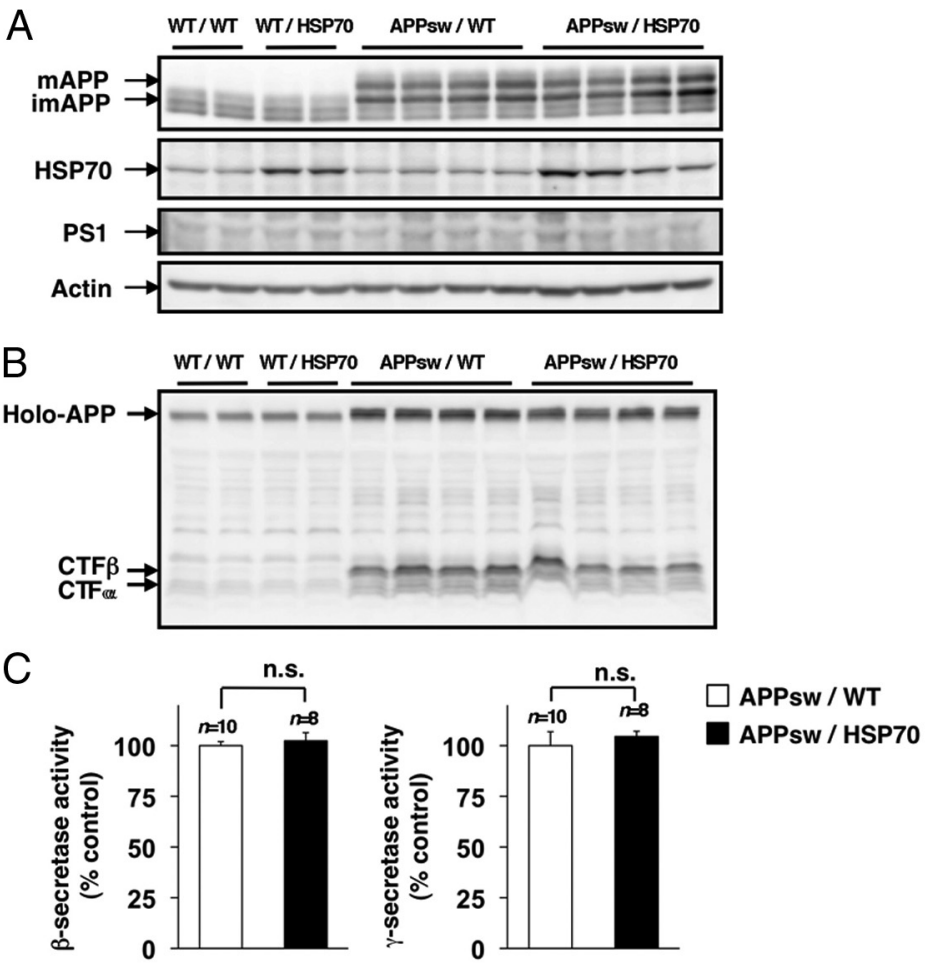

Figure 4. Effects of HSP70 overexpression on the production of $A \beta$. $A-C$, Whole-cell extracts $(A, B)$ and membrane fractions $(C)$ were prepared from the brains of 12-month-old WT/WT, WT/HSP70, APPsw/WT, and APPsw/HSP70 mice. Whole-cell extracts were subjected to immunoblotting with an antibody to $\operatorname{APP}(\boldsymbol{A}, \boldsymbol{B}), \mathrm{HSP70}(\boldsymbol{A}), \operatorname{PS1}(\boldsymbol{A})$, or actin $(\boldsymbol{A})$. Membrane fractions were d APPsw/HSP70 mice $(n=8)]$. Values are given as mean \pm SEM. n.S., Not significant $(\boldsymbol{C}$. D, E, Primary neurons prepared from to immunoblotting with an antibody to APP, HSP70, or actin (D). After incubation for $48 \mathrm{~h}$, the amounts of $A \beta 40$ and $A \beta 42$ in the conditioned medium were determined by sELISA. Values are given as mean \pm SD. n.S., Not significant (E).

$\mathrm{A} \beta$ (Miners et al., 2008). We therefore next compared the expression of genes involved in this process. Real-time RT-PCR analysis of brain samples revealed that the mRNA expression of ide, but not that of neprilysin or ece-2, was higher in the APPsw/HSP70 mice than in the APPsw/WT animals (Fig. 6A). The upregulation of mRNA expression of ide by overexpression of HSP70 was also observed in wildtype mice (without expression of APPsw) (supplemental Fig. 4, available at www.jneurosci.org as supplemental material). We also examined the effect of overexpression of HSP70 on the MRNA expression of ide in primary cultures of neurons, astrocytes, and microglia. As shown in Figure 6B, the mRNA expression of ide was higher in primary astrocyte and microglial cultures prepared from APPsw/HSP70 mice than in those from APPsw/WT mice. In contrast, no significant difference was seen in the neuronal cultures (Fig. $6 \mathrm{~B})$. These results suggest that the upregulation of $i d e$ expression is involved in the decrease in the level of $\mathrm{A} \beta$ observed in the brain of APPsw/HSP70 mice. 

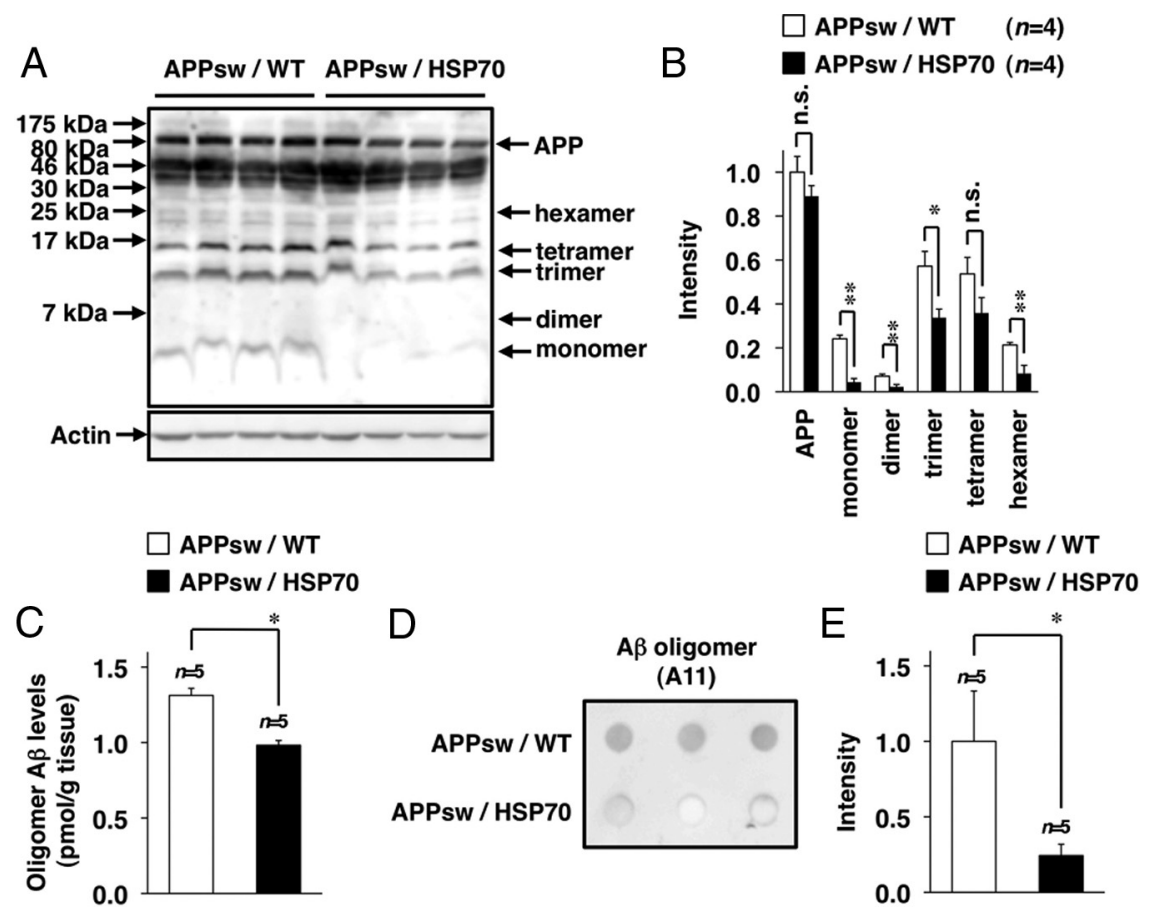

$\mathrm{D}$
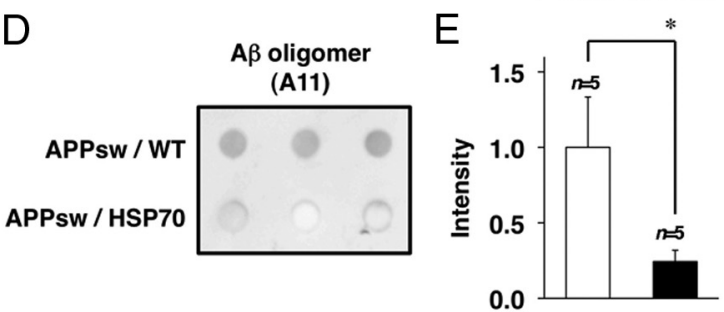

Figure 5. Effects of HSP70 overexpression on the levels of $A \beta$ oligomers in the brains of transgenic mice expressing APPsW. $\boldsymbol{A}-\boldsymbol{E}$, Whole-cell extracts $(\boldsymbol{A}, \boldsymbol{B})$ or soluble fractions $(\boldsymbol{C}-\boldsymbol{E})$ were prepared from the brains of 12 -month-old APPsw/WT and APPsw/ HSP70 mice, and then subjected to immunoblotting with an antibody to $A \beta$ (6E10) (A), ELISA for A $\beta$ oligomer [APPsw/WT ( $n=$ 5) and APPsw/HSP70 mice $(n=5)$ ] (C), or dot-blotting assay with an antibody against $A \beta$ oligomer (A11) (D). The band intensity of APP and each form of $A \beta$ was determined, corrected with that of actin, and expressed relative to the control [APPSw/WT ( $n=$ 4) and APPsw/HSP70 mice $(n=4)](B)$. The dot intensity was determined and expressed relative to the control (APP in APPsw/WT mice) $[\operatorname{APPsw} / \mathrm{WT}(n=5)$ and APPsw/HSP70 mice $(n=5)](\boldsymbol{E})$. Values are given as mean $\pm \operatorname{SEM}(\boldsymbol{B}, \boldsymbol{C}, \boldsymbol{E}) .{ }^{* *} p<0.01 ;{ }^{*} p<0.05$. n.S., Not significant.

It has been suggested that inflammation stimulates the progression of the pathogenesis of AD (Wyss-Coray, 2006). However, inflammation also activates the phagocytotic activity of microglia and astrocytes, resulting in stimulation of $\mathrm{A} \beta$ clearance (Wyss-Coray et al., 2001). Thus, the relationship between inflammation and progression of $\mathrm{AD}$ is complicated, with some proinflammatory cytokines (such as TNF- $\alpha$ ) being suggested to promote the progression of $\mathrm{AD}$, whereas others (such as IL- $1 \beta$ and IL-6) have a negative effect in mouse models of the disease (Tesseur et al., 2006; He et al., 2007; Hoshino et al., 2007b; Shaftel et al., 2007). TGF- $\beta 1$, a key cytokine regulating the response of the brain to injury and inflammation, has also been suggested to suppress the progression of AD. Therefore, we then examined the expression of cytokines that have been suggested to affect the phagocytosis of $\mathrm{A} \beta$ (IL- $1 \beta$, IL-6, TNF- $\alpha$, and TGF- $\beta 1$ ) (WyssCoray et al., 2001; Tesseur et al., 2006; He et al., 2007; Hoshino et al., 2007b; Shaftel et al., 2007). As shown in Figure 7A, the mRNA expression of tgf- $\beta 1$ in the brain was higher in the APPsw/HSP70 mice than in APPsw/WT animals. However, no differences were observed in the mRNA expression of the other cytokines (Fig. $7 A$ ). Similar results were obtained at the protein level, as judged by ELISA (Fig. 7B). The increased mRNA expression of tof- $\beta 1$ and protein level of TGF- $\beta 1$ by overexpression of HSP70 was also observed in wild-type mice (without expression of APPsw) (supplemental Fig. 4, available at www.jneurosci.org as supplemental material).

We also examined the effect of overexpression of HSP70 on the mRNA expression of tof- $\beta 1$ in primary cultures of neurons, astrocytes, and microglia. As shown in Figure $7 C$, tgf- $\beta 1$ mRNA expression was higher in the neuron and astrocyte cultures pre- pared from APPsw/HSP70 mice than in those from APPsw/WT animals. However, no such difference was observed in the microglial cultures (Fig. 7C). Together, these findings suggest that the higher expression of $t g f-\beta 1$ is responsible for the lower level of $\mathrm{A} \beta$ seen in the brains of APPsw/HSP70 mice, compared with their APPsw/WT counterparts.

Finally, we examined the effect of overexpression of HSP70 on microglial activation by immunohistochemical analysis with an antibody against Iba1 (a marker for activated microglia). As shown in supplemental Figure 5 (available at www.jneurosci.org as supplemental material), the level of Iba1 expression was higher in APPsw/HSP70 mice than APPsw/WT, suggesting that expression of HSP70 activates microglia in APP23 mice.

\section{Discussion}

HSPs have attracted considerable attention as $\mathrm{AD}$ drug targets because of their unique properties as molecular chaperones (i.e., their ability to unfold and refold abnormal proteins). Other activities of HSPs in vitro, such as cytoprotection against $\mathrm{A} \beta$ neurotoxicity, suppression of inflammation, and stimulation of $\mathrm{A} \beta$ phagocytosis, have increased this attention. Furthermore, the ameliorative effect of HSPs has also been suggested in the case of other neurodegenerative conditions, such as polyglutamine diseases and Parkinson's disease (Adachi et al., 2003; Katsuno et al., 2005; Lo Bianco et al., 2008). Despite this, no in vivo evidence exists to support the idea that HSPs are protective in vertebrate $\mathrm{AD}$ models. Therefore, in this study, we tested this idea using transgenic mouse strains expressing APPsw and HSP70.

Because $\mathrm{AD}$ results in cognitive impairment, it is important to find endogenous factors that affect not only the pathological but also the functional (cognitive) phenotypes in the animal models. This notion is supported by previous reports that some endogenous factors ameliorate cognitive dysfunction in $\mathrm{AD}$ model mice without affecting the pathological phenotypes (such as $\mathrm{A} \beta$ plaque deposition) (Roberson et al., 2007; Kanninen et al., 2009). In the present study, we found that APPsw/HSP70 mice display a higher level of cognitive function (spatial learning and memory) than APPsw/WT mice, suggesting that overexpression of HSP70 ameliorates the deficits in spatial learning and memory caused by expression of APPsw. Furthermore, we demonstrated that no significant differences in spatial learning and memory exist between WT/WT and WT/HSP70 mice, suggesting that overexpression of HSP70 does not affect the cognitive ability of wild-type mice.

We also found that there are lower levels of $A \beta$ in both the soluble and insoluble fractions of APPsw/HSP70 brains than in those prepared from APPsw/WT mice, suggesting that overexpression of HSP70 suppresses production of A $\beta$. However, no such differences were observed in the levels of CTF $\boldsymbol{\alpha}$ and CTF $\beta$, indicators of proteolysis by $\alpha$ - or $\beta$-secretase, respectively. Furthermore, the activities of $\beta$ - and $\gamma$-secretase in the brain were also indistinguishable between the two strains of mice. These in vivo re- 
sults suggest that overexpression of HSP70 does not affect the production of $A \beta$. In fact, we showed that the level of $A \beta$ in the conditioned medium was similar between HSP70-overexpressing neurons and control neurons. Inflammatory factors, such as $\mathrm{PGE}_{2}$ (prostaglandin $\mathrm{E}_{2}$ ) and proinflammatory cytokines, are known to enhance the production of $\mathrm{A} \beta$ (Wyss-Coray, 2006; Hoshino et al., 2007b, 2009), and the antiinflammatory activity of HSP70 has recently been reported (Chan et al., 2004; Sun et al., 2005; Tang et al., 2007). However, since expression of proinflammatory cytokines was not affected by overexpression of HSP70 either in vivo or in vitro, the antiinflammatory activity of HSP70 does not appear to contribute to the ameliorative effect of HSP70 in $\mathrm{AD}$ model mice.

As described in Introduction, $\mathrm{A} \beta$ is cleared from the brain through enzymemediated degradation, phagocytosis by microglia and astrocytes, and transport into the blood and lymph nodes (Miners et al., 2008; Zlokovic, 2008; Rodríguez et al., 2009). The inability of HSP70 to affect the production of $\mathrm{A} \beta$ suggests that the clearance of $A \beta$ is enhanced in transgenic mice expressing HSP70. We found that the expression of IDE, an A $\beta$-degrading enzyme, is enhanced by overexpression of HSP70 both in vitro and in vivo. We also demonstrated that the expression of TGF- $\beta 1$ is increased by overexpression of HSP70. Given that it has been reported that TGF- $\beta 1$ stimulates $\mathrm{A} \beta$ clearance through activation of phagocytic microglia (Wyss-Coray et al., 2001) and we here suggested that overexpression of HSP70 activates microglia, we consider that the lower level of $\mathrm{A} \beta$ observed in the brains of transgenic mice expressing HSP70 is attributable to the stimulation of $\mathrm{A} \beta$ clearance through upregulation of expression of IDE and TGF- $\beta 1$. In terms of the mechanism underpinning the upregulation of TGF- $\beta 1$ expression because of overexpression of HSP70, we consider a possibility that extracellular HSP70 is responsible, as it has previously been reported that extracellular HSP70 stimulates the expression of TGF- $\beta 1$ (Kimura et al., 1998).

However, there is no direct evidence to show that lower levels of $\mathrm{A} \beta$ in mice with overexpression of HSP70 is mediated by $\mathrm{A} \beta$-degrading enzyme and TGF- $\beta 1$, and thus another mechanism may be involved in the phenomenon. For example, Hsp70 might increase the degradation of $\mathrm{A} \beta$ by stimulating autophagy or Hsp70 might directly modulate the activity of microglia to degrade $\mathrm{A} \beta$.

The current findings show that the level of $\mathrm{A} \beta$ plaque deposition in the brain
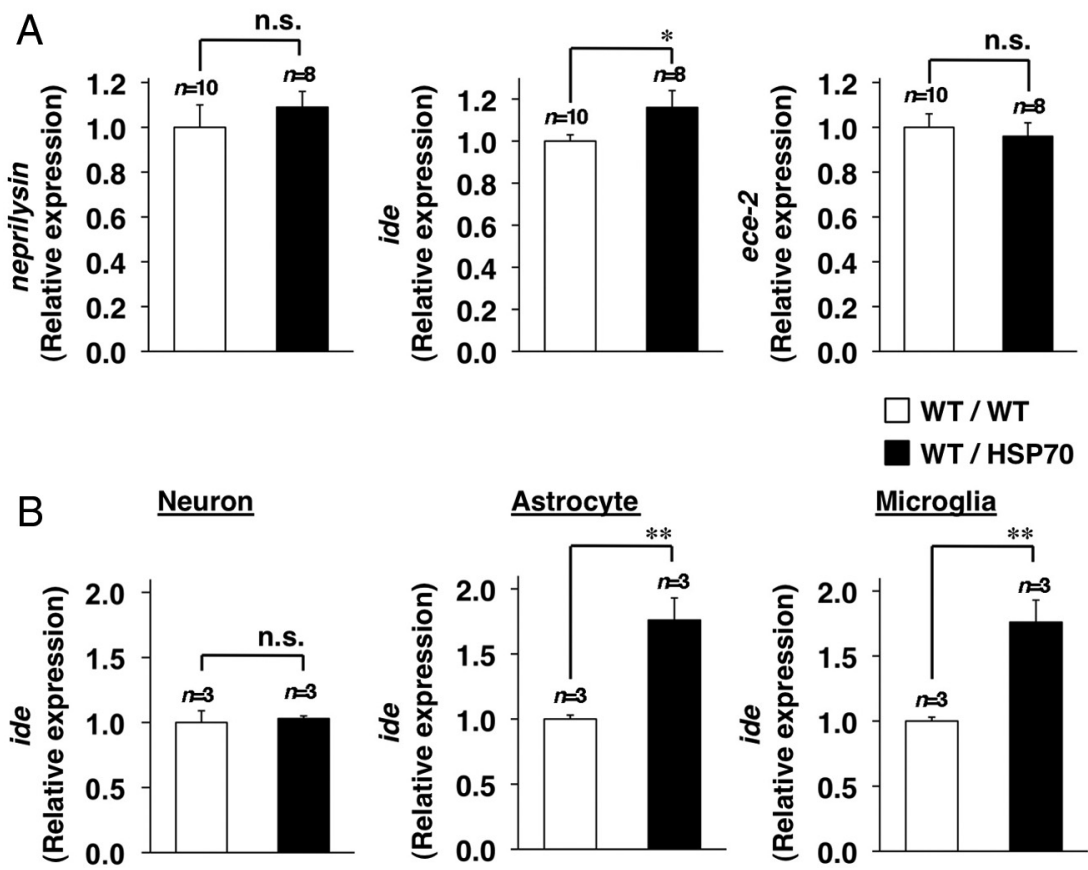

Figure 6. Effects of HSP70 overexpression on the expression of A $\beta$-degrading enzymes. $A, B$, Total RNA was extracted from the brains of 12-month-old APPsw/WT $(n=10)$ and APPsw/HSP70 mice $(n=8)(\boldsymbol{A})$ or from primary cultures of neurons, astrocytes and microglia prepared from WT/WT $(n=3)$ and WT/HSP70 mice $(n=3)(B)$. RNA samples were subjected to real-time RT-PCR using a specific primer for each gene. Values were normalized to gapdh gene expression and expressed relative to the control sample. Values are given as mean $\pm \operatorname{SEM}(\boldsymbol{A})$ or SD $(\boldsymbol{B}) .{ }^{* *} p<0.01 ;{ }^{*} p<0.05 ;$ n.s., not significant.
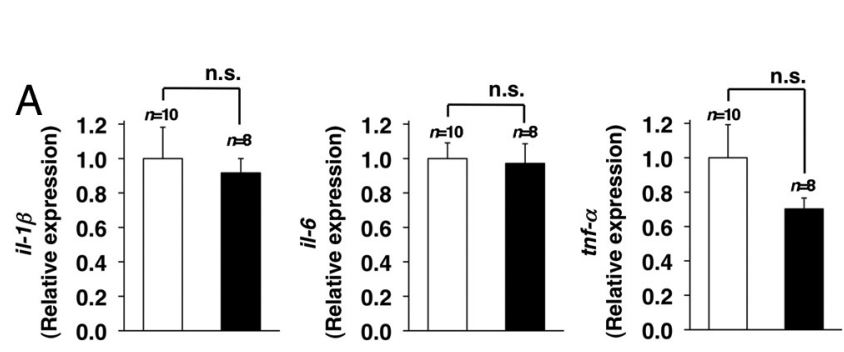

$\square$ APPsw / WT
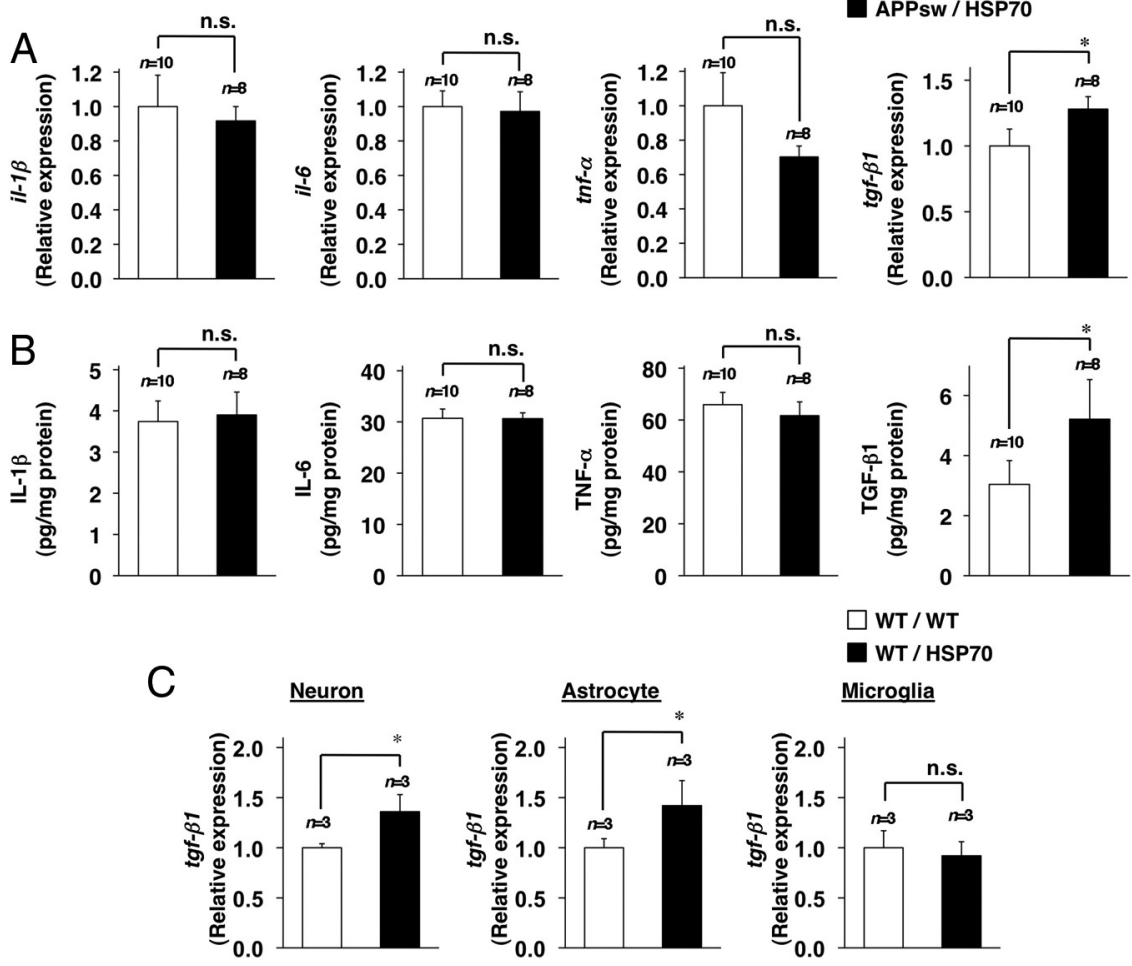

Microglia

Figure 7. Effects of HSP70 overexpression on cytokine expression. $\boldsymbol{A}, \boldsymbol{B}$, Total RNA $(\boldsymbol{A})$ or whole-cell extracts $(\boldsymbol{B})$ were prepared from the brains of 12-month-old APPsw/WT $(n=10)$ and APPsw/HSP70 mice $(n=8)$. C, Total RNA was also extracted from primary culture of neurons, astrocytes, and microglia prepared from WT/WT $(n=3)$ and WT/HSP70 mice $(n=3)$. RNA samples were subjected to real-time RT-PCR as described in the legend of Figure $6(\boldsymbol{A}, \boldsymbol{C})$. The amounts of cytokine in the whole-cell extracts were determined by ELISA $(\boldsymbol{B})$. Values are given as mean $\pm \operatorname{SEM}(\boldsymbol{A}, \boldsymbol{B})$ or $\mathrm{SD}(\boldsymbol{C}){ }^{*} p<0.05$. n.s., Not significant. 
is reduced in APPsw/HSP70 mice compared with APPsw/WT animals. We also found that the level of $\mathrm{A} \beta$ oligomers is lower in the APPsw/HSP70 mouse brain. One explanation of these phenotypes is the lower level of monomeric A $\beta$ in the APPsw/HSP70 mice than in the APPsw/WT animals. However, we believe that the antiaggregation activity of HSP70 for A $\beta$ that was suggested by previous in vitro studies (Muchowski and Wacker, 2005; Evans et al., 2006; Kumar et al., 2007; Yoshiike et al., 2008) is involved in these phenotypes. We also found that APPsw/HSP70 mice have less neuronal and synaptic loss than their APPsw/WT counterparts. Again, the phenotype can be explained by the lower level of $\mathrm{A} \beta$. However, we consider that the cytoprotective activity of HSP70 against $A \beta$-induced neuronal apoptosis that was suggested by previous in vitro studies (Magrané et al., 2004) is involved in the phenotype.

As outlined in Introduction, the beneficial effects of HSP70 in animal models of various diseases suggest the potential therapeutic benefit of HSP70 inducers for these conditions (Tanaka et al., 2007, 2010; Asano et al., 2009; Suemasu et al., 2009; Matsuda et al., 2010; Yamashita et al., 2010), a possibility that can now be expanded to include $\mathrm{AD}$ based on the results of the present study. A number of recent studies have revealed new molecules that induce HSPs (Kieran et al., 2004; Westerheide et al., 2004; Yan et al., 2004). However, the development of new candidate drugs requires them to pass through the clinical trials process, with the prospect of encountering side effects. In light of this, we have focused our attention on geranylgeranylacetone (GGA). GGA, a leading antiulcer drug on the Japanese market, has been reported to be a nontoxic HSP inducer (Hirakawa et al., 1996). GGA has also been shown to upregulate the expression of HSP70 in various tissues, including the stomach, intestine, liver, heart, eye, ear, skin, lung, and brain (Hirakawa et al., 1996; Ooie et al., 2001; Katsuno et al., 2005; Asano et al., 2009). We and another group have previously reported that GGA suppresses not only gastric lesions but also lesions of the small intestine and inflammatory bowel disease-related colitis (Ohkawara et al., 2005; Asano et al., 2009; Suemasu et al., 2009). Furthermore, we have demonstrated that GGA ameliorates the phenotype in an animal model of spinal and bulbar muscular atrophy (a polyglutamine disease) by suppressing the aggregation of pathogenic proteins (Katsuno et al., 2005). Compared with new molecules that induce HSPs, GGA has an advantage, given that its safety has already been clinically demonstrated. We therefore consider that animal and clinical studies should be performed to prove the effectiveness of GGA for preventing and treating $\mathrm{AD}$.

\section{References}

Adachi H, Katsuno M, Minamiyama M, Sang C, Pagoulatos G, Angelidis C, Kusakabe M, Yoshiki A, Kobayashi Y, Doyu M, Sobue G (2003) Heat shock protein 70 chaperone overexpression ameliorates phenotypes of the spinal and bulbar muscular atrophy transgenic mouse model by reducing nuclear-localized mutant androgen receptor protein. J Neurosci 23:2203-2211.

Asano T, Tanaka K, Yamakawa N, Adachi H, Sobue G, Goto H, Takeuchi K, Mizushima T (2009) HSP70 confers protection against indomethacininduced lesions of the small intestine. J Pharmacol Exp Ther 330:458-467.

Bradford MM (1976) A rapid and sensitive method for the quantitation of microgram quantities of protein utilizing the principle of protein-dye binding. Anal Biochem 72:248-254.

Chan JY, Ou CC, Wang LL, Chan SH (2004) Heat shock protein 70 confers cardiovascular protection during endotoxemia via inhibition of nuclear factor-kappaB activation and inducible nitric oxide synthase expression in the rostral ventrolateral medulla. Circulation 110:3560-3566.

Evans CG, Wisén S, Gestwicki JE (2006) Heat shock proteins 70 and 90 inhibit early stages of amyloid beta-(1-42) aggregation in vitro. J Biol Chem 281:33182-33191.

Farmery MR, Tjernberg LO, Pursglove SE, Bergman A, Winblad B, Näslund J (2003) Partial purification and characterization of gamma-secretase from post-mortem human brain. J Biol Chem 278:24277-24284.

Fukumoto H, Cheung BS, Hyman BT, Irizarry MC (2002) Beta-secretase protein and activity are increased in the neocortex in Alzheimer disease. Arch Neurol 59:1381-1389.

Haass C, Selkoe DJ (2007) Soluble protein oligomers in neurodegeneration: lessons from the Alzheimer's amyloid beta-peptide. Nat Rev Mol Cell Biol 8:101-112.

Hardy J, Selkoe DJ (2002) The amyloid hypothesis of Alzheimer's disease: progress and problems on the road to therapeutics. Science 297:353-356.

He P, Zhong Z, Lindholm K, Berning L, Lee W, Lemere C, Staufenbiel M, Li $\mathrm{R}$, Shen Y (2007) Deletion of tumor necrosis factor death receptor inhibits amyloid beta generation and prevents learning and memory deficits in Alzheimer's mice. J Cell Biol 178:829-841.

Hirakawa T, Rokutan K, Nikawa T, Kishi K (1996) Geranylgeranylacetone induces heat shock proteins in cultured guinea pig gastric mucosal cells and rat gastric mucosa. Gastroenterology 111:345-357.

Hoshino T, Tsutsumi S, Tomisato W, Hwang HJ, Tsuchiya T, Mizushima T (2003) Prostaglandin E2 protects gastric mucosal cells from apoptosis via EP2 and EP4 receptor activation. J Biol Chem 278:12752-12758.

Hoshino T, Nakaya T, Araki W, Suzuki K, Suzuki T, Mizushima T (2007a) Endoplasmic reticulum chaperones inhibit the production of amyloidbeta peptides. Biochem J 402:581-589.

Hoshino T, Nakaya T, Homan T, Tanaka K, Sugimoto Y, Araki W, Narita M, Narumiya S, Suzuki T, Mizushima T (2007b) Involvement of prostaglandin E2 in production of amyloid-beta peptides both in vitro and in vivo. J Biol Chem 282:32676-32688.

Hoshino T, Namba T, Takehara M, Nakaya T, Sugimoto Y, Araki W, Narumiya S, Suzuki T, Mizushima T (2009) Prostaglandin E2 stimulates the production of amyloid-beta peptides through internalization of the EP4 receptor. J Biol Chem 284:18493-18502.

Huang SM, Mouri A, Kokubo H, Nakajima R, Suemoto T, Higuchi M, Staufenbiel M, Noda Y, Yamaguchi H, Nabeshima T, Saido TC, Iwata N (2006) Neprilysin-sensitive synapse-associated amyloid-beta peptide oligomers impair neuronal plasticity and cognitive function. J Biol Chem 281:17941-17951.

Iwata N, Mizukami H, Shirotani K, Takaki Y, Muramatsu S, Lu B, Gerard NP, Gerard C, Ozawa K, Saido TC (2004) Presynaptic localization of neprilysin contributes to efficient clearance of amyloid- $\beta$ peptide in mouse brain. J Neurosci 24:991-998.

Kanninen K, Heikkinen R, Malm T, Rolova T, Kuhmonen S, Leinonen H, Ylä-Herttuala S, Tanila H, Levonen AL, Koistinaho M, Koistinaho J (2009) Intrahippocampal injection of a lentiviral vector expressing Nrf2 improves spatial learning in a mouse model of Alzheimer's disease. Proc Natl Acad Sci U S A 106:16505-16510.

Katsuno M, Sang C, Adachi H, Minamiyama M, Waza M, Tanaka F, Doyu M, Sobue G (2005) Pharmacological induction of heat-shock proteins alleviates polyglutamine-mediated motor neuron disease. Proc Natl Acad Sci U S A 102:16801-16806.

Kauppinen TM, Swanson RA (2005) Poly(ADP-ribose) polymerase-1 promotes microglial activation, proliferation, and matrix metalloproteinase9-mediated neuron death. J Immunol 174:2288-2296.

Kieran D, Kalmar B, Dick JR, Riddoch-Contreras J, Burnstock G, Greensmith L (2004) Treatment with arimoclomol, a coinducer of heat shock proteins, delays disease progression in ALS mice. Nat Med 10:402-405.

Kimura Y, Yamada K, Sakai T, Mishima K, Nishimura H, Matsumoto Y, Singh M, Yoshikai Y (1998) The regulatory role of heat shock protein 70-reactive CD4 + T cells during rat listeriosis. Int Immunol 10:117-130.

Kobayashi K, Noda Y, Matsushita N, Nishii K, Sawada H, Nagatsu T, Nakahara D, Fukabori R, Yasoshima Y, Yamamoto T, Miura M, Kano M, Mamiya T, Miyamoto Y, Nabeshima T (2000) Modest neuropsychological deficits caused by reduced noradrenaline metabolism in mice heterozygous for a mutated tyrosine hydroxylase gene. J Neurosci 20:2418-2426.

Kumar P, Ambasta RK, Veereshwarayya V, Rosen KM, Kosik KS, Band H, Mestril R, Patterson C, Querfurth HW (2007) CHIP and HSPs interact with beta-APP in a proteasome-dependent manner and influence Abeta metabolism. Hum Mol Genet 16:848-864.

Lo Bianco C, Shorter J, Régulier E, Lashuel H, Iwatsubo T, Lindquist S, 
Aebischer P (2008) Hsp104 antagonizes alpha-synuclein aggregation and reduces dopaminergic degeneration in a rat model of Parkinson disease. J Clin Invest 118:3087-3097.

Magrané J, Smith RC, Walsh K, Querfurth HW (2004) Heat shock protein 70 participates in the neuroprotective response to intracellularly expressed $\beta$-amyloid in neurons. J Neurosci 24:1700-1706.

Matsuda M, Hoshino T, Yamashita Y, Tanaka K, Maji D, Sato K, Adachi H, Sobue G, Ihn H, Funasaka Y, Mizushima T (2010) Prevention of UVB radiation-induced epidermal damage by expression of heat shock protein 70. J Biol Chem 285:5848-5858.

Mattson MP (2004) Pathways towards and away from Alzheimer's disease. Nature 430:631-639.

Mima S, Tsutsumi S, Ushijima H, Takeda M, Fukuda I, Yokomizo K, Suzuki K, Sano K, Nakanishi T, Tomisato W, Tsuchiya T, Mizushima T (2005) Induction of claudin- 4 by nonsteroidal anti-inflammatory drugs and its contribution to their chemopreventive effect. Cancer Res 65:1868-1876.

Miners JS, Baig S, Palmer J, Palmer LE, Kehoe PG, Love S (2008) Abetadegrading enzymes in Alzheimer's disease. Brain Pathol 18:240-252.

Morimoto RI, Santoro MG (1998) Stress-inducible responses and heat shock proteins: new pharmacologic targets for cytoprotection. Nat Biotechnol 16:833-838.

Muchowski PJ, Wacker JL (2005) Modulation of neurodegeneration by molecular chaperones. Nat Rev Neurosci 6:11-22.

Ohkawara T, Nishihira J, Takeda H, Miyashita K, Kato K, Kato M, Sugiyama T, Asaka M (2005) Geranylgeranylacetone protects mice from dextran sulfate sodium-induced colitis. Scand J Gastroenterol 40:1049-1057.

Ooie T, Takahashi N, Saikawa T, Nawata T, Arikawa M, Yamanaka K, Hara M, Shimada T, Sakata T (2001) Single oral dose of geranylgeranylacetone induces heat-shock protein 72 and renders protection against ischemia/reperfusion injury in rat heart. Circulation 104:1837-1843.

Perez N, Sugar J, Charya S, Johnson G, Merril C, Bierer L, Perl D, Haroutunian V, Wallace W (1991) Increased synthesis and accumulation of heat shock 70 proteins in Alzheimer's disease. Brain Res Mol Brain Res 11:249-254.

Plumier JC, Ross BM, Currie RW, Angelidis CE, Kazlaris H, Kollias G, Pagoulatos GN (1995) Transgenic mice expressing the human heat shock protein 70 have improved post-ischemic myocardial recovery. J Clin Invest 95:1854-1860.

Plumier JC, Krueger AM, Currie RW, Kontoyiannis D, Kollias G, Pagoulatos GN (1997) Transgenic mice expressing the human inducible Hsp70 have hippocampal neurons resistant to ischemic injury. Cell Stress Chaperones 2:162-167.

Roberson ED, Scearce-Levie K, Palop JJ, Yan F, Cheng IH, Wu T, Gerstein H, Yu GQ, Mucke L (2007) Reducing endogenous tau ameliorates amyloid beta-induced deficits in an Alzheimer's disease mouse model. Science 316:750-754.

Rodríguez JJ, Olabarria M, Chvatal A, Verkhratsky A (2009) Astroglia in dementia and Alzheimer's disease. Cell Death Differ 16:378-385.

Saito Y, Sano Y, Vassar R, Gandy S, Nakaya T, Yamamoto T, Suzuki T (2008) $\mathrm{X} 11$ proteins regulate the translocation of amyloid beta-protein precursor (APP) into detergent-resistant membrane and suppress the amyloidogenic cleavage of APP by beta-site-cleaving enzyme in brain. J Biol Chem 283:35763-35771.

Shaftel SS, Kyrkanides S, Olschowka JA, Miller JN, Johnson RE, O’Banion MK (2007) Sustained hippocampal IL-1 beta overexpression mediates chronic neuroinflammation and ameliorates Alzheimer plaque pathology. J Clin Invest 117:1595-1604.

Sturchler-Pierrat C, Abramowski D, Duke M, Wiederhold KH, Mistl C, Rothacher S, Ledermann B, Bürki K, Frey P, Paganetti PA, Waridel C, Calhoun ME, Jucker M, Probst A, Staufenbiel M, Sommer B (1997) Two amyloid precursor protein transgenic mouse models with Alzheimer disease-like pathology. Proc Natl Acad Sci U S A 94:13287-13292.
Suemasu S, Tanaka K, Namba T, Ishihara T, Katsu T, Fujimoto M, Adachi H, Sobue G, Takeuchi K, Nakai A, Mizushima T (2009) A role for HSP70 in protecting against indomethacin-induced gastric lesions. J Biol Chem 284:19705-19715.

Sun D, Chen D, Du B, Pan J (2005) Heat shock response inhibits NF-kappaB activation and cytokine production in murine Kupffer cells. J Surg Res 129:114-121.

Tanaka K, Namba T, Arai Y, Fujimoto M, Adachi H, Sobue G, Takeuchi K, Nakai A, Mizushima T (2007) Genetic evidence for a protective role for heat shock factor 1 and heat shock protein 70 against colitis. J Biol Chem 282:23240-23252.

Tanaka K, Ishihara T, Azuma A, Kudoh S, Ebina M, Nukiwa T, Sugiyama Y, Tasaka Y, Namba T, Ishihara T, Sato K, Mizushima Y, Mizushima T (2010) Therapeutic effect of lecithinized superoxide dismutase on bleomycin-induced pulmonary fibrosis. Am J Physiol Lung Cell Mol Physiol 298:L348-L360.

Tang D, Kang R, Xiao W, Wang H, Calderwood SK, Xiao X (2007) The anti-inflammatory effects of heat shock protein 72 involve inhibition of high-mobility-group box 1 release and proinflammatory function in macrophages. J Immunol 179:1236-1244.

Tesseur I, Zou K, Esposito L, Bard F, Berber E, Can JV, Lin AH, Crews L, Tremblay P, Mathews P, Mucke L, Masliah E, Wyss-Coray T (2006) Deficiency in neuronal TGF-beta signaling promotes neurodegeneration and Alzheimer's pathology. J Clin Invest 116:3060-3069.

Tomita S, Kirino Y, Suzuki T (1998a) Cleavage of Alzheimer's amyloid precursor protein (APP) by secretases occurs after $O$-glycosylation of APP in the protein secretory pathway. Identification of intracellular compartments in which APP cleavage occurs without using toxic agents that interfere with protein metabolism. J Biol Chem 273:6277-6284.

Tomita S, Kirino Y, Suzuki T (1998b) A basic amino acid in the cytoplasmic domain of Alzheimer's beta-amyloid precursor protein (APP) is essential for cleavage of APP at the alpha-site. J Biol Chem 273:19304-19310.

Van Dam D, D’Hooge R, Staufenbiel M, Van Ginneken C, Van Meir F, De Deyn PP (2003) Age-dependent cognitive decline in the APP23 model precedes amyloid deposition. Eur J Neurosci 17:388-396.

Wang J, Ho L, Chen L, Zhao Z, Zhao W, Qian X, Humala N, Seror I, Bartholomew S, Rosendorff C, Pasinetti GM (2007) Valsartan lowers brain beta-amyloid protein levels and improves spatial learning in a mouse model of Alzheimer disease. J Clin Invest 117:3393-3402.

Westerheide SD, Bosman JD, Mbadugha BN, Kawahara TL, Matsumoto G, Kim S, Gu W, Devlin JP, Silverman RB, Morimoto RI (2004) Celastrols as inducers of the heat shock response and cytoprotection. J Biol Chem 279:56053-56060.

Wyss-Coray T (2006) Inflammation in Alzheimer disease: driving force, bystander or beneficial response? Nat Med 12:1005-1015.

Wyss-Coray T, Lin C, Yan F, Yu GQ, Rohde M, McConlogue L, Masliah E, Mucke L (2001) TGF-betal promotes microglial amyloid-beta clearance and reduces plaque burden in transgenic mice. Nat Med 7:612-618.

Yamashita Y, Hoshino T, Matsuda M, Kobayashi C, Tominaga A, Nakamura Y, Nakashima K, Yokomizo K, Ikeda T, Mineda K, Maji D, Niwano Y, Mizushima T (2010) HSP70 inducers from Chinese herbs and their effect on melanin production. Exp Dermatol 19:e340-e342.

Yan D, Saito K, Ohmi Y, Fujie N, Ohtsuka K (2004) Paeoniflorin, a novel heat shock protein-inducing compound. Cell Stress Chaperones 9: $378-389$.

Yoshiike Y, Minai R, Matsuo Y, Chen YR, Kimura T, Takashima A (2008) Amyloid oligomer conformation in a group of natively folded proteins. PLoS One 3:e3235.

Zlokovic BV (2008) The blood-brain barrier in health and chronic neurodegenerative disorders. Neuron 57:178-201. 